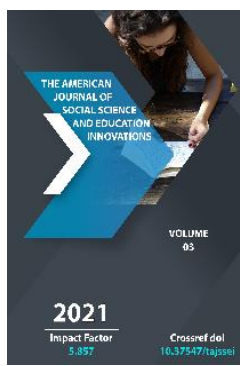

\title{
Translations Of Category Plots Into Uzbek Literature
}

\author{
Ozoda Tohirovna Tojiboeva \\ Doctor Of Philosophy (PhD) In Philology, Teacher, Tashkent State University Of Uzbek \\ Language And Literature Named After Alisher Navoi, Uzbekistan
}

Journal Website:

http://usajournalshub.c om/index,php/tajssei

Copyright: Original content from this work may be used under the terms of the creative commons attributes 4.0 licence.

\section{ABSTRACT}

A series of plot works of a formative nature are common in Eastern literature. The works of Firdavsi, Nizami Ganjavi, Khisrav Dehlavi, Alisher Navoi, consisting of seven works depicting the image of Bahrom, have been published in different versions in oral literature. Such works, which contain many incisive events in one work, were loved and read by the people of their time. In Uzbek literature, such works have been translated and reworked from Persian-Tajik. This article provides information on a prose translation of "Bahrom and Gulandom". Information is provided on the authors who carried out the translation and on the process of its publication in lithographic printing. The study of works of Uzbek literature, such as "Bahrom and Dilorom", "Bahrom and Gulandom", analyzes some aspects of tradition and originality.

\section{KEYWORDS}

Molding plot, hamsa, reader, prose, verse, translation.

\section{INTRODUCTION}

Works with a series of plots are widespread in world literature. The influence of works of Indian literature such as "Tutinoma", "Kalila and Dimna" was also strong in the spread of stereotypes in the literature of the peoples of the East. While Firdavsi's epic "Shohnoma" was the basis of the epic "Khamsa", these five great epics marked the development of the 
literature of the period. Alisher Navoi's epic "Sab'ai Sayyar" is widely studied in Turkish literature. The epics of Alisher Navoi's "Khamsa" were reworked by later artists. Various variants in the form of prose stories were created in folklore. Although there are variants of "Farhod and Shirin", "Layli and Majnun" close to the epics of Navoi or other Hamsanavis, which continue on the basis of a certain eventful plot; The works based on the plot of "Sab'ai Sayyar" are relatively free and independent. The works of Bahrom in the literature of the peoples of the East are not limited to the epics "Khamsa". This plot line in the modeling series reached its peak in the works of Hamsanavis, served as a basis, an ideological source for future works.

\section{THE MAIN FINDINGS AND RESULTS}

In the XVIII-XIX centuries, the role of short stories in the folklore was much higher, and due to the strong tendency of the people to legendary works, biblical epics were also recreated in the folklore. Many variants of romantic-adventure, war-heroic type stories have been created. During this creative process, folk tales with the main heroes "Farhod, Majnun, Bahrom, and Iskandar were created. Unlike other epics of "Khamsa", there are two versions of the works in which the image of Bahrom is involved - Bahrom and Dilorom, Bahrom and Gulandom. As a result of the interest in storytelling works such as "A Thousand and One Nights", "Kalila and Dimna", which attracted the attention of readers in terms of compositional structure in world literature, there was a need for this category of works in Uzbek literature.

The scientist M.Muhiddinov, who studied the evolution of the image of Bahrom, their interpretation in the literature on the basis of various sources, compares the works of two categories - "Bahrom and Gulandom", "Bahrom and Dilorom" (on the example of Bahrom Gor), shows their differences (4, 2007). Analyzes the following works in the series "Bahrom and Dilorom": epics by Hamsanavis writers based on this plot; The epic "Shah Bahrom and Dilorom" by the Uyghur writer Gharibi, written in Uzbek, in exact analogy with Navoi's epic; Translation of Agahi's Nizami Haft Paykar; Prose statement of Alisher Navoi's "Khamsa" "Story of the week Bahrom" in "Nasri Khamsai Benazir". Among these works, "Nasri Khamsai Benazir" was published in 1908 in the printing house of Orifjanov, in which the prose of "Khamsa" epics "Farhod and Shirin”, "Layli and Majnun”, "Sab'ai Sayyar", "Saddi Iskandariy" were narrated. In it, the epic "Sab'ai Sayyar" is traditionally called "Qissai haft manzari Bahrom" and does not deviate from the original.

The works in the Bahrom and Gulandom series are heroic-adventure works that are far removed from the Khamsa epics. Literary critic B. Murtazaev, who studied Alisher Navoi's "Sabai Sayyar" and Khisrav Dehlavi's "Hasht Behisht" epics in his dissertation, notes that these stereotypes continued in the following centuries in two directions: 1. The hunting conflict between the king and the maid 2 . Separate adventures of a king and a concubine. At the same time, these stereotypes accelerated the emergence of the great epics Bahrom and Gulandom" (3, 1991: 56).

The popularity and popularity of the version of "Bahrom and Gulandom" is associated with the name of Sabir Sayqali. The epic "Bahrom and Gulandom", created by Sabir Sayqali, has led to the proliferation of works of the same name in folklore. 
The works of the series "Bahrom and Gulandom" appeared in folklore, passed from mouth to mouth along with many heroic stories and epics, the first examples of which were written in Persian-Tajik language and reflected in the form of pure prose and poetry. It was introduced into Uzbek literature by Sabir Sayqali" (4, 2007: 160). In translating, Sayqali translates the work into poetry and brings it to the written literature. The folk epic "Bahrom and Gulandom" by Fozil Yuldash oglu was also created under the influence of Sayqali's work.

In general, such popular works as "Varqa and Gulshah”, “Qissai Jamshid”, “Qissai Rustam”, "Qissai Kahramoni Kotil" were written in Persian-Tajik language, but were read by both peoples. Alisher Navoi's “Khamsa” inspired the creation of many works of literature of fraternal peoples, folklore, while the products of Persian-Tajik literature also contributed to the development of Uzbek literature.

Translational literature has also developed due to cooperation in intercultural relations, the process of exchange in a variety of plots, and the translations made in order to make the Uzbek reader enjoy these works. After Navoi's Sab'ai Sayyar, the translation of works such as Kalila and Dimna, A Thousand and One Nights, Chor Darvesh, and Haft Kishvar, which were not included in Uzbek literature, was one of the sources that enriched Uzbek prose in this direction. (2, 1970: 60).

The role and influence of translated literature in the development of science, culture and literature of the late XIX and early XX centuries was great. It is known that the Khorezm School of translation of the XIX century functioned effectively enriched the bisot of Uzbek literature with translated works. This tradition, the creative process, the cultural atmosphere in Tashkent continued in a more vivid and colorful way. A significant part of the news in Tashkent is related to the names of lithographic printing houses operating in the city. Many classics were published in them, translated from other languages. At the same time, a number of Bahrom and Gulandom works were translated and published by publishers. During this period, a number of folk books based on the plot of "Khamsa" published in lithography are directly related to the names of Siddiqi Khandayliqi and Khislat.

Siddiqi Khandayliqi and Khoja Haybatullohkhoja Khislat are among the most prolific artists who lived and worked in Tashkent in the early twentieth century. Along with their creative work, they made a significant contribution to Uzbek literature through their translation, calligraphy, painting and publishing activities. Khislat re-edited and published Alisher Navoi's epics "Farhod and Shirin", "Layli and Majnun" by Umar Baki. Siddiqi Khandayliqi copied it on stone, worked on paintings under the pseudonym Shavkat. Khislat also translated such works as "Dostoni Barzuyi sher" (Firdavsi), "Cat and Mouse" (Ubayd Zakani). There is information that Nizami also translated the epic "Layli and Majnun" in prose (1, 2008: 72$)$.

\section{RESULTS AND DISCUSSIONS}

His friend Siddiqi Khandayliqi, a thinker and friend of Khislat, translated the Persian-Tajik work "The Story of Prince Bahrom and Princess Gulandom". The work was published in 1911 by Gulomiya printing house. The translation was made on the recommendation of Siddiqui's friend, bookseller Mirzo Ahmad Mirzokarimboy. Scholar M. Muhiddinov identifies the sources on which this translation is based and compares it with the copy printed 
in 1901 in Navlakshur printing house in Laknov (4, 2007: 139-145). It seems that as a result of cooperation between publishers and booksellers in cultural and educational relations, it is possible to acquaint readers with different interpretations of traditional plots, which in turn served for the development of both literatures.

There is another translation of the work of the same name that has not been analyzed in previous studies. The book was published two years after Siddiqi's translation in 1913 at the Asia Printing House in Tashkent. The title page provides information about the people responsible for its creation: "The sons of the translator Mullo Abdullah Haji Mirkarimboy are probably the sons of Mullo Zufar Shukur Muhammad". So, the work was translated by Mullo Abdullah Haji and published under the auspices of the book merchant Mullo Zufar. Calligrapher Abdulhamid Qori. The book contains nine black-and-white photographs in accordance with the content of the work. In the margins of the photos is a small inscription: "Humble number Abdulhamid". The translator explains the factor that led to the creation of the work as follows: "It simply came to our notice then. Scientists, in particular, are eager to learn about the past. Within the science of Tavorix, more and more people are immersed in the story of the lover. When the story of a lover is told at every meeting, the soul hears it with its ears, and it is too much to hear. Indeed, the science of Tawheed is a good science, and it has many benefits".

The translator enumerates the differences in the interests of the scholar and the people, enumerates the benefits of reading and listening to the book, and describes the client of the translation as follows: "No in bliss and prophecy, and Sa'dinama in poetry and poetry, in the truest sense Navoiyoso ani Sayid Haybatullohkhoja khislat ibn Sayid Orifkhoja ibn Sayid Mahmudkhoja ibn Sayid Norkhoja is the book of the story of Bahrom and Gulandomnama, the book of the story of Bahrain and Gulandomnama. He said, "If I publish it in the press, Muslims will benefit from it".

It turns out that the person who led the creation of the translation of the work is the Attribute. This information is not found in the data on the life and work of the Character. It is clear from the comparative comparisons that this translation has exactly the same beginning and meaning as the translation made by Siddiqui. However, the information in the introductory part partially clarifies the reason why this work was performed again. The interpreter reports the situation as follows: "Mr. Petitioner says that although this book was translated by the poet in the robe of a poet on horseback. But the exact translation is not universal, but less so. I did not publish it for the sake of Ani and again for the sake of poetry".

The work begins as a translation by Siddiqui. In general, the comparison of works in this series helps to reveal the commonalities in the literature of the Uzbek and fraternal peoples.

\section{CONCLUSION}

It seems that all the prose works created, the translations made in the prose were born on the basis of the needs and requirements of the people for works of art. Although all of them were created earlier, they were re-created, edited, adapted to the peculiarities of the period, popularized in the late XIX and early XX centuries, and the existing ones were published in lithographs. All of them serve to enrich the scope of Uzbek prose. It also enriches the Uzbek literature with a series of 
plot works and expands the object of study. Makes it possible to compare with Persian copies. In general, intellectuals living in the early 2oth century were leaders in the preservation, publication and popularization of Uzbek classical literature. Today, it is important to study these manuscripts and pass them on to future generations.

\section{REFERENCES}

1. Karimov N. (2008). Landscapes of twentieth-century literature. - Tashkent: O'zbekiston. (Каримов H. XX аср адабиёти манзаралари. - Т.: O’zbekiston, 2008.)

2. Komilov N. (1970). Muhammadrizo Agahi's translation skills. Dissertation for Candidate of Philological Sciences. Tashkent. (Комилов Н. Мухаммадризо Огахийнинг таржимонлик махорати. Фил фан ном дисс. - Т. 1970.)

3. Murtazaev B. (1991). Comparative analysis of Alisher Navoi's "Sab'ai Sayyar" and Khisrav Dehlavi's "Hasht Behisht" epics. Dissertation for Candidate of Philological Sciences. - Tashkent. (Муртазаев Б. Алишер Навоий “Сабъаи сайёр” ва Хисрав Дехлавий “Хашт бехишт” достонларининг қиёсий тахлили. Филол фан ном дисс. -Т.: 1991).

4. Muhiddinov M. (2007). Bouquet of radiant hearts. - Tashkent: Fan. (Мухиддинов М. Нурли қалблар гулшани. -Т.: Фан, 2007.)

5. Navoi Alisher. Khamsa. Prepared by P.Shamsiev. - Tashkent: Publishing House of the Academy of Sciences of the Republic of Uzbekistan. 1960. - p. 854. (Навоий Алишер. Хамса. Нашрга тайёрловчи П.Шамсиев. - Тошкент: ЎзРФА нашриёти, 1960. - 854 6.)

6. Navoi Alisher. Layla and Majnun. Sabai Sayyor. - Tashkent: Gafur Gulom Publishing
House, 2012. - р. 696. (Навоий Алишер. Лайли ва Мажнун. Сабъаи сайёр. Тошкент: Ғафур Ғулом номидаги нашриёт-матбаа ижодий уйи, 2012. - 696 б.)

7. Navoi Alisher. Sabai Sayyor. (With prose statement) - Tashkent: Publishing and printing association. 1991. - p. 544. (Навоий Алишер. Сабъаи сайёр. (Насрий баёни билан) -Т.: Нашриёт-матбаа бирлашмаси, 1991. -544 б.)

8. Rasuljanovna, I. N. (2019). THE PHENOMENON OF LACUNARITY AS THE LINGUACULTURAL ISSUE. PROSPECTS OF WORLD SCIENCE-2019, 226. 